\title{
Nők a közgondolkodásban - a kisdedóvónő, mint lehetséges „karrierút” a XIX. század végi pedagógiai szakfolyóiratok tükrében
}

\author{
JANEK NOÉMI \\ Eötvös Loránd Tudományegyetem, Tanító- és Óvóképző Kar
}

\begin{abstract}
A szerző jelen tanulmányban a XIX. század végi pedagógiai folyóiratok nökröl való gondolkodásának vizsgálatát végezte el, kiemelt hangsúlyt helyezve a korszak egy lehetséges női hivatására, a kisdedóvói pályára. A századra jellemzö általános nöneveléssel kapcsolatos gondolataival indul az irás, amit a folyóiratok tartalmának mélyebb elemzése követ. A nök közgondolkodásban való megjelenésének tanulmányozása három fó témacsoport mentén történik, így az akkori társadalomban betöltött szerepük, lányok nevelésének tartalmi és gyakorlati kérdései és lehetséges hivatásai, valamint a kor szerzöi szerinti hiányosságaik. Külön fejezetrészben kerül bemutatásra a korszak egy lehetséges nöi „karrierútja”, igy a nők kisdedóvó pályára történö bekerülése, képzésük lehetöségei és a velük szemben támasztott elvárások mibenléte. A téma a Nemzeti Nönevelés, Kisdednevelés és a Kisdedóvók és gyermekkertésznők lapjának 1880-1885 között megjelent számai alapján került vizsgálatra.
\end{abstract}

Kulcsszavak: nötörténet, lánynevelés-történet, óvóképzés, pedagógiai folyóirat, tartalomelemzés

\section{Bevezetés}

Ebben a tanulmányban a nők közgondolkodásban betöltött helyét, a nevelésükkel kapcsolatos föbb nézeteket, valamint a korszak lehetséges női karrierlehetőségét vizsgálom a XIX. század végén megjelent folyóiratok lapszámaiban, így a Nemzeti Nőnevelésben (1880-1882), Kisdednevelésben (1880-1885) és a Kisdedóvók és Gyermekkertésznők Lapjában (1881-1882). Az első lap a nőnevelés általános kérdéseivel foglalkozik, míg a másik kettő címükből is kitűnően jellemzően az óvókkal és a kisdedóvás ügyével. Ezeket azért tartottam mégis relevánsnak, mert a korszakban írt cikkek tanúsága szerint a lehetséges női hivatások leginkább e területre koncentrálódtak.

A bevezetésben a XIX. század nőneveléssel kapcsolatos általános nézeteit tekintetem át, majd a felsorolt sajtóorgánumok tartalomelemzését végzem el, előzetesen meghatározott szempontok mentén, kiemelt figyelmet szentelve a kisdedóvónői pálya megjelenésére.

\section{A XIX. századi nőnevelésről általában}

Először érdemes röviden áttekinteni a század nőneveléssel kapcsolatos főbb vélekedéseit, a nők közgondolkodásban betöltött szerepét, hiszen ezek mélyebb betekintést nyújthatnak a nők tanulmányi lehetőségeinek alakulására, potenciális elhelyezkedési esélyeikre vonatkozóan.

A népiskolai oktatás a fiúk és a lányok számára a XIX. század elején hely hiánya miatt még koedukált formában zajlott, de az elkülönítésre való törekvés már jellemezte ezt az időszakot, hiszen a II. Ratio Educationis (1806), majd a Magyarország elemi tanodáinak szabályzata (1845) is ennek megfelelően rendelkezett (Pirka, 2014). A változást az 1868. évi XXXVIII. törvénycikk a népoktatásról hozta meg, ami előírta a 6-12 éves korig tartó egységes tankötelezettséget és megteremtette a hat osztályos népiskolát, melyben mind a lányok és fiúk ugyanazt a tananyagot sajátíthatták el. A lányok számára ezután polgári iskola és tanitónőképzó állt rendelkezésre a további tanulmányok folytatásához. A középpolgárság leányainak viszont 
Nők a közgondolkodásban - a kisdedóvónő, mint lehetséges „karrierút”...

ez nem jelentett megoldást, hiszen a képzés gyakorlatiassága miatt szükségleteiknek nem felelt meg. E probléma orvoslására Veres Pálné ösztönzésére Molnár Aladár tett lépéseket, így kidolgozta a hatévfolyamos felsöbb leányiskola tervezetét, ami 1875-ben meg is nyílt Budapesten. Ez a képzés érettségi bizonyítvány megszerzését ugyan nem biztosította, így továbbtanulásra sem adott lehetőséget, célja csupán a humán müveltséggel rendelkezö családanya és feleség szerepére való felkészítés volt. 1869-ben Eötvös József nőtanító-képző intézetet állított Budán, ennek élére Zirzen Janka került kinevezésre, akit a „nőtanítók anyjaként” is említenek.

Ebben a korszakban a nők nevelésére vonatkozóan két markánsan eltérő nézetet különböztethetünk meg. Az egyik szerint életfeladatuknak a jó feleséggé és édesanyává válás, a családról való gondoskodás tekinthető, amihez nem szükséges a magasabb szintű tudás és képzettség megszerzése. E véleményen volt Fáy András, aki szerint a nőnek „női mivoltát” elfogadva, visszavonultan, a külvilággal szemben tartózkodóan kell, hogy teljesítse anyai és gazdaasszonyi teendőit. Ennek értelmében úgy vélte a polgári élethez kellő praktikus ismeretek elsajátítása szükséges, ilyen a józan háztartásvezetés, a józan pénzköltés elveinek alkalmazása, a „magyar polgárné" kötelességeinek ismerete, a társalgás és az illedelmes viselkedés szabályainak követése (Pukánszky, 2006).

Ekkoriban nőnevelő intézeteket létesített Karacs Teréz is, ahol a nők férfiak mintájára történő nevelésének igénye megjelent ugyan, ám ennek ellenére Karacs Teréz a család ellen ható tényezőnek tekintette a nők munkába állásának támogatását. A képzés így elsősorban szintén a családanyává váláshoz járult hozzá, tartalmát olyan gyakorlati ismeretek képezték, mint a nöi kézimunka, szabás-varrás, fehérnemü készítés. Ezeken kívül megjelent a francia nyelv, zene, tánc és szépirás oktatása is, továbbá a nő szépérzékének fejlesztése és a férfiak gyönyörködtetésére szolgáló foglalatosságok gyakorlása.

Ezzel szemben a kor másik jellemző vélekedése a nők férfiakkal való egyenjogúsá- gának eszméjét hirdette, tehát e szerint számukra is elérhetővé kell tenni a magasabb szintű elméleti tudás elsajátítását, ami lehetőséget biztosíthat a családból való kilépés$\boldsymbol{h e z}$, társadalmi életben történő önállóságuk érvényesítéséhez.

A korszak másik nagy női egyénisége, Brunszvik Teréz maga is úgy vélte, hogy a feleségnek férje méltó társává kell lennie, de nem csupán a tűzhely őreként, hanem szellemi síkon is, ennek érdekében a lányok számára szintén lehetővé kell tenni a magasabb színvonalú tanulmányok elvégzését. A nőket az emberiség "másik, fontosabb felének" (Pukánszky, 2006. 40. o.), a józan ész birtoklóiként nevezi, akik számára elengedhetetlen a rendszeres és alapos iskolai felkészítés. E kijelentések mellett a férfiak által tanult magasabb műveltség tartalmát erőteljesen bírálta, „klasszikus ostobaságként” aposztrofálva azt. Szerinte az elvont tudományok helyett alkalmazott tudás megszerzése a kívánatos, valamint az erkölcsi fejlödés szerepét is nagyra értékelte.

Pesten Brunszvik unokahúga, Teleki Blan$k a$ nyitott nőnevelő intézetet foúri leányok számára, ami a Karacs-féle miskolci intézettel szemben elsődleges céljának az anyanyelv ápolását és a magyar kultúra megörzését tüzte ki célul. Itt a korábbiakkal ellentétben már megjelentek emancipációs törekvések, így például a felsőfokú egyetemi képzés megnyitásának gondolata a nők előtt, amire ugyan csak a század végén kerülhetett sor (Pukánszky, 2006).

Mindezen tények alapján érzékelhető, hogy a XIX. században még nem létezett egységes koncepció a nők nevelésének intézményi és tartalmi vonatkozásában, valamint lehetséges hivatásaikkal kapcsolatban sem. Mindenképpen kiemelhető viszont a családban betöltött szerepük fontosságának hangsúlyozása, mint a nők legfőbb életfeladata, így a legtöbb képzés, amit a korszakban kaphattak leginkább a családi életre való felkészítést helyezte középpontjába. 


\section{A nők megjelenése a közgondolkodásban a folyóiratok tükrében - 1880-1885}

A három választott folyóirat ezen időszakában élénk diskurzus zajlott a nönevelés és a nôi pályaválasztás kérdéseivel kapcsolatban. Ez leginkább a Nemzeti Nőnevelés folyóiratot jellemzi, aminek címéből is következtethetünk a tartalmában megjelenő témakörökre. A másik két folyóirat viszont abból a szempontból érdekes, hogy a korszak egy lehetséges női „karrierútjának” kibontakozásába nyerhetünk mélyebb betekintést. A tartalomelemzés módszerét alkalmazva vizsgáltam a folyóiratok tartalmát, ami alapján a következő három fő csomópont mentén végzem el elemzésem:

- a nö helye és szerepe a társadalomban - kiváltképpen az anya és feleség szerepkörére vonatkozóan;

- lányok nevelésének tartalma és gyakorlata, ezzel szoros összefüggésben a kívánatosnak tekinthető női hivatások; és a

- a nők hiányosságainak („ferdeséginek”) fejtegetéseire vonatkozó nézetek megjelenése.

\section{A kor női szerepei - anya és feleség}

A Nemzeti Nőnevelés 1880-ban írt vezércikkében Péterfy Sándor (a lap föszerkesztője) a nők feladatainak jelentőségét taglalja - „ti viszitek karjaitokon a kisded nevendéket s jó polgárrá nevelitek; ti nemes tekintetetekből szí a férfi lelki erőt s elszánt bátorságot”, „ti vagytok a polgári erény s nemzetiség védangyalai" (Péterfy, 1880. 1. o.).

Gondolataiból kitűnik a korszellemnek megfelelően az anyaság és asszonyság jelentősége, de túl is mutat ezeken, hiszen a nemzet védőangyalainak szerepével is felruházza őket. Ez összefüggésben állhat azzal, hogy ebben az időszakban kiemelt jelentőséggel bírt a magyar kultúra felvirágoztatásának eszméje, aminek szolgálatába akarták állítani a leányiskolákat is, mégpedig a magyar irodalom, zene, képzőművészeti alkotások tanítása által. Ennek jelentőségét abban látták, hogy a lányok magyar anyává válva, leendő gyermekeiket is hasonló szellemben, hazájukat szerető, magyar polgárokká neveljék.

Lederer szintén a háziasszonyi és anyai szerep felelősségteljes mivoltát fejtegette egyik cikkében, amiben ezen szerepek rossz müködését tette felelőssé azért, ha a családi otthon a civakodás, szerencsétlenség és nyomor színhelyévé válik. Emellett a férj elhajlásának okozóját (például kocsmába járás, tolvajlás) is az asszonyban vélte meglátni (Lederer, 1880).

Szvorényi az anyai mellett az atyai szerepkör fontosságát is megemlíti, de tartalmasabban inkább a nők szerepéről értekezik. Ö is anyai hivatásukban látja kiteljesedésük lehetőségét, mely során „bölcs anyai szerelemmel" kell gondozni, nevelni, tanítani a gyermeket, valamint az első nevelőjévé válnia. Bánóczi „A Nőkről” című cikkében (Bánóczi, 1880) globálisabb nézőpontból indíttatva a társadalom szemléletformáló erejéről ír. Szerinte a társadalom formálja a maga képére a nőt, így ennek függvénye, hogy az adott korszakban „asszonyi állatként”, „vászoncselédként” vagy „feleségként” tekintenek-e rá. Megkérdőjelezi a nők önállóságát, hisz úgy véli nagy alkalmazkodóképességük a férfihoz köti őket, aminek következtében saját nézeteikről, gondolataikról le kell mondanak férjük javára. A korábbiakhoz hasonlóan ő is a már sokat említett kívánatos szerepkört említi meg: „természetes hivatása a családi életre utal” (Bánóczi, 1880. 78. o.). Viszont mindezekkel szemben azt is fejtegeti, hogy a társadalom szervezete, amilyen arányban az bonyolódik, úgy növekszik az elvárás a tagjaikkal szemben is. Ezért a nök felszabaditását szorgalmazza, némileg pejoratív kicsengésü gondolatában ezt így fejezi ki, ha a rabszolgákat és a gondolatokat is szabadon engedték, akkor ideje lenne már a nőknek is szabaddá válniuk és a társadalom munkásaivá lenniük. Szemlélete túlmutat a családi életen, így a kívánatos női munkák közül a tanítóságot említi meg, mint a leghasznosabb, bár leghálátlanabb hivatást. Az egyenjogúsági törekvéseket ő sem tartja támogatandónak, mert szerinte, amíg nem a férfi lesz anya szerepben, addig teljes 
Nők a közgondolkodásban - a kisdedóvónő, mint lehetséges „karrierút”...

felszabadítás nem is jöhet létre, hisz „nő szüli ugyan a férfiút, de a férfi alkotja a törvényt” (Bánóczi, 1880. 78. o.).

Legfőképpen nőnek és anyának kell len$n i$ - ez már Szász cikkében olvasható és ezt kiegészítve említi (Brunszvik Teréz korábbi gondolatához hasonlóan), hogy a nő férje müvelt társává is köteles válni, azaz szellemi társsá válni a hivatása. A nő értelmi szintjének emelését annyira tartja csak fontosnak, hogy férje számára kielégítő legyen társasága, valamint gyermekét is megfelelően nevelni képessé váljon általa (Szász, 1882.).

Mindezekből arra a következtetésre juthatunk, hogy ugyan fontosnak tartották a nők műveltségét, de magasabb szellemi tevékenységre alkalmatlannak vélték őket. Leginkább a család ellátása, gyerekkel való foglalatoskodás, mint prioritás jelenik meg. Ezzel szemben ugyanakkor nagy felelősséget is társítottak szerepükhöz, nem csak a családi életet tekintve, hanem az egész nemzetet illetően is.

\section{A nő nevelése és hivatása}

A nőnevelés kérdései és a számukra kívánatos pályák élénken foglalkoztatták a folyóiratok szerzőit. Csengery Antal a nőnevelés elhanyagolásának problémáját veti fel, hiszen szerinte a nők helyzete egy adott társadalomban jól példázza a nemzet műveltségének szintjét, így ebből a szempontból sem mellőzhető e kérdés. A női emancipáció mellett ugyan nem érvel, hiszen szerinte a nők nem láthatnak el minden munkát, amit a férfiak képesek elvégezni. Kiemel viszont olyan kvalitásokat, amik a különböző hivatásokra megfelelőbbé teszik őket - így például ő is a tanitói hivatást említi, mint leginkább nőkre szabott tevékenységet javasolja (Csengery, 1880).

A nők különböző pályára való alkalmasságának taglalásáról több cikkben is olvashatunk: „vannak, a kik a nőt mindenre képesnek állítják, a mire a férfi képes, abból indulván ki, hogy a férfi és a nő között nincs faji különbség" (Szász, 1882. 9. o.) és a női munkakörök kiszélesítését sürgetik, viszont ezen a véleményen csupán kevesen osztoztak ebben az időszakban.
Ennek ellenére többen is értekeztek a $\boldsymbol{k i}$ vánatos női foglalatosságokról, így például a nőiparoktatásról, aminek célját a középosztály leányai számára a tisztességes megélhetés biztosításában látták. Ugyanakkor egyes szerzők úgy vélték, hogy ez a tevékenység csupán egy parasztasszony igényeinek megfelelő mellékkeresetet jelenthet, így nem ad lehetőséget a valós önállósodásra. Felszólaltak a gyakorlati képzés fontossága mellett a csak elméleti képzéssel szemben.

Stetina Ilona viszont a nők szerzett ismereteinek felhasználhatóságát vitatta, erősen bírálva a hasztalan csillogásra, bámultatásra buzdító iskolai tartalmakat. A háztartási teendők elvégzéséhez szükséges ismereteket vélte elsődlegesnek, hisz ez a társadalom müvelt, hasznos tagjává válás biztosítéka - elsődleges fontosságú az, hogy a nő „tudását és munkáját mennyiben bírja családja s így a nemzete javára értékesíteni" (Stetina, 1880. 226. o.).

György Aladárné mindezekkel szemben sajnálnivalóként gondol azon nőkre, akik elvből vagy kényszerítő okból kifolyólag lemondanak a családi élet boldogságáról és munkába állnak.

Érdekes, hogy a női szerzők maguk is úgy vélték, hogy a nőnek a helye a „tüzhely” mellett van, mert ez által válik a társadalom számára hasznossá és értékessé a tevékenysége, így nem álltak ki ők sem a nők magasabb iskolázottsága mellett (György, 1880).

A neveléssel kapcsolatos hivatások áttekintése elengedhetetlen, hiszen ezen a területen a nők térhódítása volt tapasztalható ebben az időszakban, így a Nemzeti Nőnevelés mellett a kisdednevelői szaklapokban is előtérbe kerültek az ilyen tartalmú cikkek.

Mind a Kisdednevelésben és a Nemzeti Nőnevelésben megjelenő írások tanúsága szerint hasonlatos álláspontra helyezkedtek el a szerzők, vagyis a korszaknak megfelelöen a nő legfőbb feladatának az anyává válást tartották. Emellett a különböző álláslehetőségeket is számba vette mindkét lap.

Áldásos női munkának e tekintetben elsősorban a gyermekkertésznői vagy óvónői pályát nevezte meg Somogyi a Kisdednevelésben közölt egyik cikkében. Kiemelte, hogy 
túl sok tanulást várnak el egy nőtől, hiszen régebben egy pár hónap alatt elvégezhető képzés elég volt a képesítés megszerzéséhez, míg ebben az időszakban már két éves tanfolyam elvárt például a gyermekkertésznői állás betöltéséhez (a Fröbel-féle Gyermekkertben alkalmazták őket). Hosszabb képzést semmiképpen sem tartott megfelelönek, mert véleménye szerint a tanulás által a nőből „valami tudákos mixtum compositum" válik (Somogyi, 1884. 87. o.).

Az óvónői szakmán kívül a házi tanitóságot, női kézimunka tanitóságot, népiskolai két első osztály tanitóságát, valamint kivételes esetben - amennyiben férfi nem tudja ellátni - a közép és felső tisztán leányosztályok vezetését nevezte meg. A nem nevelői munkák közül a pénztárnoki, postamesternői valamint az üzletekben való elárusítói tevékenység került a kívánatos foglalkozások listájára (Somogyi, 1884) (1. ábra).

A Nemzeti Nőnevelés ugyanezen témakörében írt cikkei viszont csak a tanítói pályát említik meg a neveléssel foglalkozók közül, mint a nőnek leginkább üdvözítő foglalkozást. Ebben a lapban egyébként is a tanítóság kerül előtérbe dominánsabban az óvókkal szemben. Ennek egy lehetséges oka az, hogy úgy vélték a kisdedkorban az anya a legalkalmasabb a gyermek gondozására, szellemi és lelki erőinek kibontakoztatására, így nem támogatták a kora gyermekkor ezen időszakának intézményes nevelését.

A nők foglalkoztatásával a Kisdedóvók és Gyermekkertésznők lapja is foglalkozik, bár nem olyan mélyrehatóan, mint a másik kettő. Ahol „Képzett férfiak nem kellettek, - jók lettek az olcsóbb nők" (Vegyesek, 1882. 12. o.) - olvasható ez a sokatmondó megállapítás. Ezen túlmenően a falusi gyermekmenhelyek kapcsán - olyan helységekben volt szükséges az állítása, hol kisdedóvó nincsen - is írtak a nőkről, mint a kívánatos munkaerőről, mégpedig a következő módon: olyan személyek alkalmasak erre a feladatra, akik „18-30 év közötti, életkedvvel rendelkező, gyermekké válni képes, türelmes és képes maga iránt tiszteletet ébreszteni" (Kobány, 1882). Ugyan olcsó munkaerőnek tartották őket és nem olyan szakképzettnek, mint a férfiakat, mégis magas elvárásokat támasztottak velük szemben, mind erkölcsi, mind a felkészültség és nevelői magatartás tekintetében, ami a morális életükkel kapcsolatban is többször leírásra került.

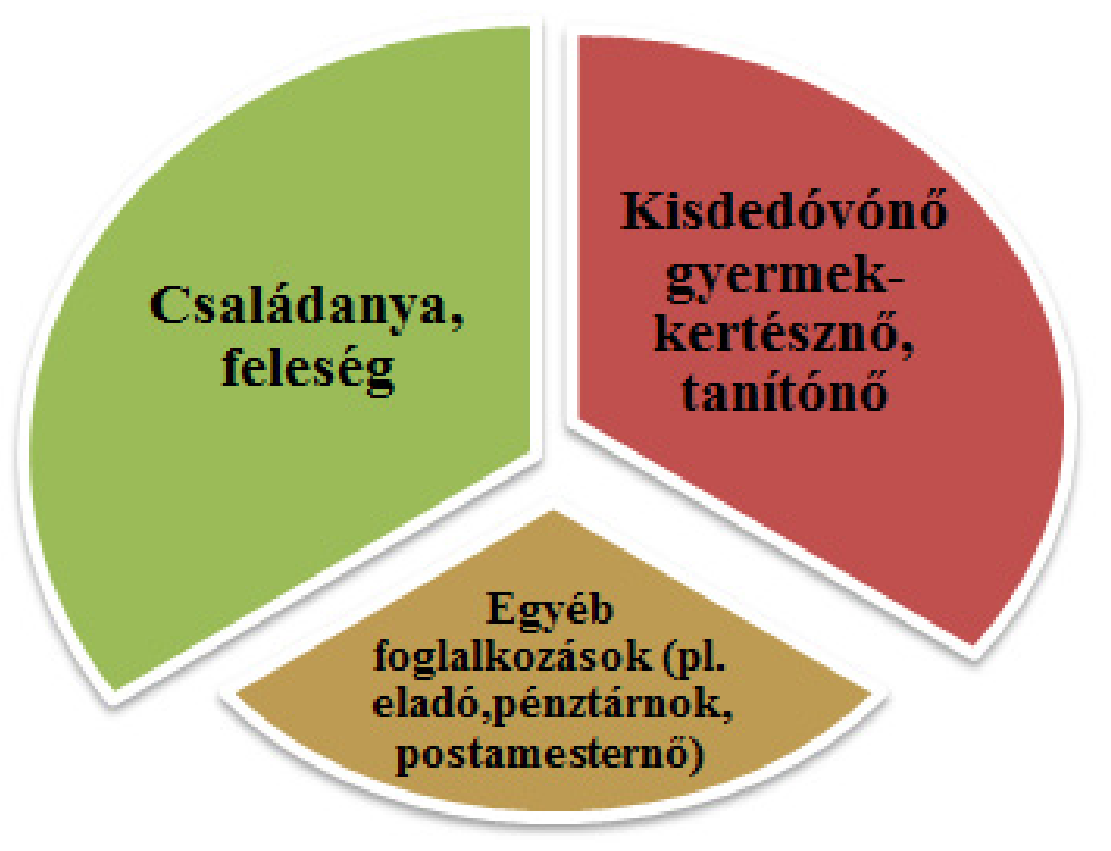

1. ábra: Kívánatos női szerepkörök megoszlása a XIX. század végi cikkekben 
Nők a közgondolkodásban - a kisdedóvónő, mint lehetséges „karrierút”...

\section{A nők „ferdeségéről”}

A nők foglalkoztatásának kérdésével összefüggésben hangsúlyt kapott a morális életük kérdése, mert attól tartottak, hogyha a nevelőnő személye „kétes” megítélés alá esik a társadalom - főképpen más anyák és nőtársak által -, akkor nem viszik gyermeküket a kisdedóvodába, ami egyértelműen a kisdedóvás ügyének felvirágoztatása ellen ható tényező. Ezen túlmenően úgy vélték, hogy nekik az egész város előtt példá$\boldsymbol{v a l}$ kell előjárni a bizalom megnyerése végett, mely segítségével a családi nevelésre is befolyást tudnak gyakorolni. 1880-ban írt „Erkölcsi élet a kisdednevelés terén" című cikkben (Dixi, 1880) sajnálatos tényként olvashatunk arról, hogy a kisdednevelőnők 10\%-a erkölcsileg elbukottnak tekinthető (erre a következő példákat említik: titkos helyeken találkozások, késő esti órákban férfi látogatók fogadása, nyilvános öszszejöveteleken udvarlás engedése - nős férfitól is). Ennek visszaszorítása érdekében javasolják feljegyzések készítését és nyilvánosságra hozatalát azokról, akiknek a tisztasága megkérdőjelezhető (Dixi, 1880). Erre az általam áttekintett lapszámokban ugyan példát nem találtam, de ebből is érzékelhető, hogy viszonylag magas elvárásokat támasztottak a nőkkel szemben és „romlott” viselkedésük esetén kilátásba helyezték a nyilvános megszégyenítésüket is, míg a férfiak esetében nem tekintették ezeket súlyos erkölcsi vétségeknek.

A Nemzeti Nőnevelés is említi a nök ferdeségének problematikáját - „a társadalom még soha nem volt annyira eltelve a nők ferdeségei ellen emelt panaszokkal, mint épen napjainkban" (Péterfy, 1880. 241. o.). Bünösként a leányiskolákat és a leánynevelési rendszert nevezi meg Péterfy, viszont bővebben nem tér ki e „ferdeségek” részletezésére. Szerinte a tanítónőképzés nem kellő szelekciója tehető ezért felelőssé „boldog boldogtalant, készületlent és jól felkészülteket egyaránt nem csak felvettek a tanítónőképző intézetekbe, hanem tanítónőkül alkalmazták is." (Péterfy, 1880. 352. o.)

„Lélektani vádak a nők ellen” címmel közölte a folyóirat Alexander Bernát tanulmányát (Bernát, 1880) melyben a szerző egy pedagógus ba- rátja lányokkal szembeni „vádjait” veszi sorba, mely következtetéseket a tapasztalatai alapján írt le. „Leginkább a leányok emlékező tehetsége ellen szokott kikelni" említi, (Bernát, 1880. 133. o.), amit azzal magyarázott a pedagógus, hogy nincs meg bennük az „igazság iránti érdeklődés", habár kíváncsi természetűek, de nem akarnak tudást szerezni. Emellett hiányzik belölük a tiszta, objektivv érdeklödés is, így csak azok a dolgok keltik fel figyelmüket, amik érdekeikkel találkoznak. A cikk szerzője ugyan a nők védelmére kelt, de úgy vélte hiába, hiszen tapasztalata szerint „háladatosabb dolog a nőket nők előtt vádolni, mintsem védeni" (Bernát, 1880. 134. o.) Azt is taglalja, hogy a férfiak kevéssé ismerik a nőket, így nem is értik meg őket igazán mélyen, valamint a férfiak általánosításra való hajlamát is okként említi. Ennek kapcsán felsorol néhány általánosított gondolatot például a „férfi aktiv természetű, a nő inkább passzív”, „a nő kiegészítése a férfiúnak”, „a nő legyen nő; valódi hivatása a család”, „a nő nem való elvont tudományokra”, „nem kell a kék harisnya” (Bernát, 1880. 137. o.). Ezekből kiérződik az az általános társadalmi nézet, miszerint a nők férfiakhoz való „hasonlósága” megkérdőjelezhető és csupán a férfi kiegészítőjeként tekintenek rájuk. A szerző azt is kiemeli, hogy a nők sem ismerik a férfiakat kellően, hiszen „megvannak a maguk kis világában." és e kölcsönös meg nem értettségből származnak a két nem közötti vádaskodások. Érzékletesen tükrözi a közgondolkodást egy, a nőegyletekről szóló cikk kiragadott szánakozónak tűnő mondata, mely szerint „ne szidjuk folytonosan szegény nőket” (György, 1880. 29. o.).

Összességében elmondható, hogy az áttekintett időszakban a nőkkel összefüggésben leginkább a nevelés kérdéseiröl lehetett olvasni, illetve arról, hogy tulajdonképpen mi is a nö életfeladata, életének értelme és célja. Egyes vélekedések azon a nézeten voltak, hogy szükséges a magasabb szintü oktatás, ugyanakkor még ezek a gondolatok sem tekinthetők egységesnek. A tartalmat tekintve széles skála mentén sorakoztatták fel azokat az érveket, hogy mi lehet a „művelt” nő számára szükséges tudás, amit még a férfitársadalom is „elbír”. Ami érdekes, hogy maguk a 
női szerzők sem gondolták úgy, hogy a nőknek szükséges a magasabb műveltség elérése, sőt a női munkavégzést többen sajnálatosnak tekintik, hiszen a legfőbb feladatuktól - az otthon melegének megteremtésétől, ápolásától vonja el őket. A gyermeknevelés, mint fö feladatuk behatóan tárgyalt téma, a Nemzeti Nőnevelés sok olyan témájú cikket közölt, amelyben az anyai teendőket említi és nevelési segédlettel is szolgál ehhez.

\section{A korszak egy lehetséges női „karrierútja” - kisdedóvónők és gyermekkertésznők képzése}

Az első magyar kisdednevelö-intézetet Tolnán alapították 1836-ban, amelyet később Pestre a Valero utcába költöztettek át 1843-ban. Ebben az időszakban kizárólag férfiakat képezhettek ki kisdedóvónak, a felvett növendékek előéletüket tekintve változatos képet mutattak egy visszaemlékezés tanúsága szerint (P. Szabó, 1882): „volt köztünk az élet delén álló férfiu, 15 éves suhanc, volt olyan, aki sok iskolát végzett, aztán olyan a ki irni-olvasni is alig tudott becsületesen"(P. Szabó, 1882. 44.).

Elsőként 1858-ban Krigovszky Antóniát alkalmazták óvónőként, aki a képzést ugyan nem végezte el, csak némi gyakorlati ismeret megszerzése után került álláshelyére. A képző első beiratkozott női tanulója nem sokkal később, 1862-ban Deréky Hermin volt, innentől pedig a nők ténylegesen megjelenhettek a képzőben és képesítést is szerezhettek a kisdedóvói hivatás gyakorlásához (Végh, 1937).
A nők kisdedóvóképzőbe történő belépésének kritériumairól egy 1880-ban írt cikkben is olvashatunk, hiszen a férfiak mellett (18 év felett) nők (16 év felett) is felvételt nyerhettek a képzőintézetbe. A felvételi kritériumok között szerepelt az ép, egészséges test, melyet igazolnia is kellett megfelelő dokumentum csatolásával, valamint az intézet orvosa is megbizonyosodott minderről. Ez azért lehetett lényeges, mert az egészséges életmódra törekvés ebben az időszakban kiemelt szerepet kapott a folyóiratok cikkeiben, hiszen nagy volt a gyermekhalandóság (nem csak balesetek, hanem egészségügyi mulasztások miatt is), melynek visszaszorítása nemzeti érdek volt. A kisdednevelönek valószínűleg ebben is mintaadó szerepet kellett betöltenie, így fontos volt az egészséges testalkat és életmód. A mentális egészségre ugyan külön nem tértek ki, de annyiban érdemes szót ejteni róla, hogy 1880-ban egy vezetőnő megőrülése kapcsán érintőlegesen foglalkoztak e problémával, ami szerintük a nők alkalmazása óta elterjedni látszott. „Rövid idő alatt már ez a 6- vagy 7-ik eset, hogy óvónő megtébolyodott" olvasható a Budapest józsefvárosi kisdedóvó egylet jelentéséből (1880, 10. o.) és azt is fejtegették, vajon a pálya okolható-e ezért a negatív tendenciáért. A XX. század elején megjelent Kisdednevelés évfolyamaiban is visszatérő probléma, csak példaként kiemelve néhányat: „éhenhalt óvónő, aki évek óta idegbajban szenvedett" (1913) „kiugrott a vonatból” (1914), „öngyilkos óvónő" (1914).

További kritériumként a nőknek legalább az $V$. elemi elvégzése, míg a férfiaknak a $I V$.

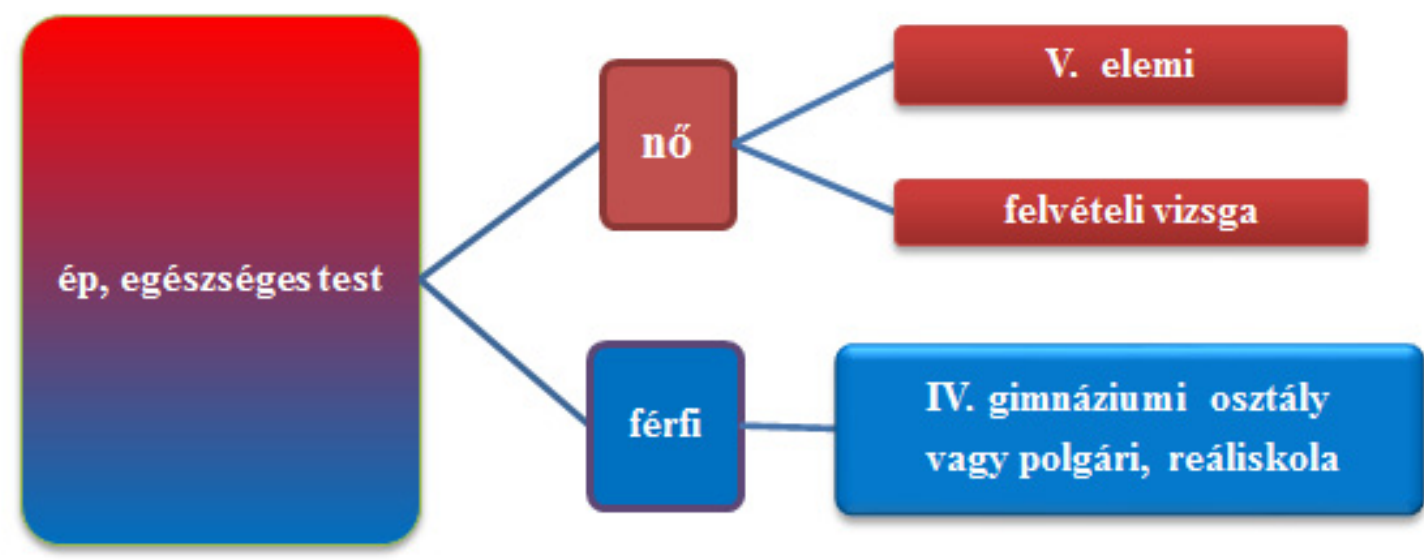

2. ábra: Azonosságok és különbözőségek a nők és férfiak óvóképzőbe történő felvételekor (1880-as évek) 
Nők a közgondolkodásban - a kisdedóvónő, mint lehetséges „karrierút”...

gimnáziumi osztály (vagy polgári, reáliskola) elvégzése kötelező volt. Emellett a nőknek még külön felvételi vizsgát is kellett tenniük, amit a férfiaktól nem vártak el. Itt érzékelhető a különbségtétel már a felvétel kapcsán is a nők és férfi jelentkezők között (2. ábra), annak ellenére, hogy ezt a hivatást inkább a nők számára tartották nyitottnak már ebben az időszakban. 1882-ben a felvételi korhatárt módosították a 16-ról a 18. életévre. Ezen kívül a női tanulók elterjedésével már egyenruháról is rendelkeztek, azért, hogy a „növendékek között a hiúságra és egymással való vetélkedésre minél kevesebb legyen az alkalom" (Végh, 1937. 65. o., 1. 2. ábra).

A korszakban a tanfolyam két évig tartott (1875-ben), ami elvégzése után képesítővizsgát kellett tenniük a növendékeknek. Olyan tantárgyakat hallgattak, mint neveléstan, módszertan, test- és egészségtan, magyar nyelv és irodalom, történelem, természettudományos tárgyak (természettan, természetrajz, számtan, vegytan, földrajz), valamint müvészeti tárgyak (zene és ének, rajz, női és kisdedóvodai kézimunkák). Az első évben leginkább az elméleti képzés folyt, a második évben pedig gyakorlaton voltak a tanulók, akik egymást váltva foglalkoztak a gyerekekkel (Tisza, 1880).

Egy másik cikkből a Fröbel-nőegylet által támogatott gyermekkertésznő képzést ismerhetjük meg mélyebben. A Fröbel-féle kisdednevelési rendszert többen megfelelőbbnek, kívánatosabbnak vélték a gyermekek számára a természetes nevelés eszméje miatt (Mikonya, 2014). A nőegylet 1869-től kezdve négy Fröbel-gyermekkertet tartott fent a fövárosban, valamint egy gyermekkertésznőképző intézetet is. Ez szintén két évfolyamos képzés volt, ahova ekkoriban 25 növendéket vehettek fel és a szegény sorsúakat segélyben, ösztöndíjban részesítettek. Kiemelten fontosnak vélték itt a női kézimunkát, jellemképző mivolta miatt a gyakorlati hasznán kívül, így olyan erények kifejlesztését, mint a türelem, pontosság és a figyelem.

A tárgyak között ebben az intézetben az első évben nevelés és módszertan, torna és egészségtan, magyar nyelvtan, történet, ter- mészettudományos tárgyak (természetrajz, számtan, földrajz), müvészeti tárgyak (rajz, zene, ének), valamint munkagyakorlat. A második évben a meglévők mellett olyanokat tanultak, mint természettan, vegytan, írástan, történelem, szabó-munka és házi ipar. A gyakorlati képzés során a növendékek minden második délelőttöt a gyermekkertben töltötték (Péterfy, 1882). A tantárgyakat tekintve szinte ugyanazokat lehetett itt is tanulni, mint a fentebb említett képzőben.

A falusi menedékházak terjesztése érdekében az „egyszerü, de értelmes írni-olvasni tudó nőket" (Végh, 1937. 64. o.) kívánták alkalmazni, akik az okleveles kisdedóvó mellett kitanulhatták az ehhez szükséges ismereteket.

\section{A férfiak kiszorulása, a nők térhódítása - presztízsvesztés?}

1880 és 1890 között megkétszereződött a kisdednevelők létszáma Kelemen említése szerint „ennél nagyobb mértékben a hagyományosan férfi »óvókat « felváltó óvónők száma” (Kelemen, 2000. 140. o.) P. Szathmáry Károly 1884-ben írt cikksorozatában (Felelet a kisdednevelés terén felmerült aggodalmakra IIII.) aggodalmát fejezi ki a pálya elnőiesedésével kapcsolatban, leginkább az anyagi okokat figyelembe véve. Legnagyobb problémának azt tartja, hogy a képezdében sem lesznek ezáltal férfi tanárok. Említése szerint ekkoriban még volt a képzőnek férfi tanulója, ám „ritkán nyerhetünk olyanokat, a kik a kisdedóvás pedagógiai színvonalát nagyon emelnék" ( $P$. Szathmáry, 1884, 143.o) Kiemeli viszont a nők pályára való alkalmasságát, hiszen a gyermekek nevelését „minden nemzet az anyáknak adta át" (P. Szathmáry, 1884, 143. o.) és nőegyesület áldásos tevékenységét is említi a kisdedóvás terén.

1885-ben Eötvös K. L. cikkében olvashatunk arról, hogy a képzőintézet bővítése szükségessé vált a népszerüsége miatt. Ebből azt is megtudhatjuk, hogy az 1885. évben már egyáltalán nem volt férfi tanulója az intézetnek. Vélekedése szerint a nagyobb tudású férfi hallgatótársaktól sokat tanulhattak korábban a nők - „mily szép eredményekre 
vezetett a férfi és nőhallgatók nemes vetélkedése" (Eötvös, 1885. 49. o.). Szerinte a kisdednevelés színvonala országszerte csökkenést mutatott és ez azzal magyarázható, hogy immáron csak nöi pályaként van jelen, ezáltal a magasabb előképzettséggel, szaktudással rendelkező férfiak teljesen kiszorultak, ami szakma presztízsének alakulására negatívan hatott (Eötvös, 1885).

Ezt a cikket követően olvashatunk a föszerkesztő tollából egy választ, aki szerint az Eötvös által említett korszakban (1870-es évek) igaz lehetett e vélekedés, viszont azóta a képzési idő megváltozott, valamint az ott nyújtott szakismeretek és a képzésbe felvettek előzetes iskolai végzettsége is magasabb színvonalúvá vált, így nem a nők tehetők felelőssé a presztízscsökkenésért. (Dömötör, 1885).

A szakma presztízsével összefüggésben Székely egy cikkében az önképzés fontosságára hívja fel a figyelmet, amin belül megkülönbözteti a szakképzésre vonatkozó, illetve az általános műveltségre irányuló továbbképzést. Úgy véli az egymástól való tanulás, valamint a gyakorlati tapasztalatok megosztása a munkakedv miatt is fontos tényező. A továbbképzést emellett társadalmi presztízs alakulása szempontjából is kiemeli, miszerint „saját elméjének művelése és akaratának erkölcsi iránybani erősödése által fölemeli szellemi tőkéjének kamatjait azon nivóra, mely őt a tisztelet és elismerés tárgyává teszi az emberiség előtt” (Székely, 1884, 44.o.)

\section{A javadalmazás kérdései - elvárások a kisdedóvónővel szemben}

AKisdednevelésben olvashatókállomáshelyek betöltéséről szóló pályázatok, amelyekből rálátásunk nyílhat azokra a kritériumokra, amiket az óvókkal szemben támasztottak, valamint a javadalmazásukra is. 1881-ben kényelmes lakást, házi kertet, 400 forint évi fizetést és két öl tüzifát ajánlottak egy törökszentmiklósi állás javadalmazásaképpen ( $\mathrm{Va}$ dai, 1881). Egy másik, pápai álláshirdetésben három szobás lakás, 400 forint évi fizetés, valamint nyolc öl tüzifa vagy ennek megfele- lő kőszén az óvoda fütéséhez. Kritériumként említett a képzettség, kifogástalan erkölcsi magaviselet és a tiszta magyar nyelv ismerete (Antal, 1882). A nyelvkérdés a XIX. század végi kisdedügyét is erősen jellemzi, hiszen kiemeltnek tartották, hogy a gyermekek első nyelve (anyanyelve) a magyar legyen, így elvárásként jelent meg az álláspályázatokban is.

Egy másik pályázat is hasonló javadalmazást ígér Szegeden, így szabad lakás, 400 forint évi fizetés, valamint fütés (Salamon, 1882). Egy újonnan megnyíló állomáshoz is okleveles óvónőt vagy gyermekkertésznőt kerestek Monorra. Itt a javadalmazás tisztességes lakás, három öl tűzifa, havi négy forint a dajka fizetésére, évi 100 forint segélydíj az egylettől. Ennél óvásdíjat számolnak fel, ami gyerekenként 50 korona, téli hónapra 20 gyerek, nyárira 40 gyerek biztosított az egylet által (monori nőegylet igazgatósága, 1882) 1883-ból is hasonló javadalmazást látni, így a 400 forintnyi éves fizetés, szabad lakás, fütés. Erre az állásra (Körmöczbánya) csak oklevéllel rendelkező óvónőt vettek fel, aki magyarul, németül tökéletesen beszél, valamint a tót nyelvet is ismeri (Chabada, 1883), hiszen ez a területen nagy számban élt német lakosság. Mindenképpen érdemes kiemelni, hogy ebben az időszakban az óvónői és a tanítónői javadalmazás azonos mértékű volt, amire a pálya megbecsültségének szempontjából mindenképpen pozitívan tekinthetünk.

Mindezekből látható, hogy akkoriban az anyagi javadalmazás mellé természetbeli juttatások is kapcsolódtak, lakás, valamint általában főként tűzifa. Viszont érdemes azt is megjegyezni, hogy a folyóirat szerzői szerint a 400 forintos évi fizetés nagyon alacsonynak számított, hiszen ez csupán szűkös megélhetést biztosított az óvóként dolgozó nő számára (3. ábra)

Az elvárásokkal összhangban érdemes a kívánatos nevelöi magatartást is röviden áttekinteni, vagyis azt hogy milyen konkrét elvárásokat támasztottak a nőkkel szemben ebben az időszakban Leginkább kiemelt a nevelő őszinte, valódi, józan és igazságos szeretete a gyermekek iránt, mert ezt vélték a nevelés legfőbb eszközének, amire minden gyerek 
Nők a közgondolkodásban - a kisdedóvónő, mint lehetséges „karrierút”...

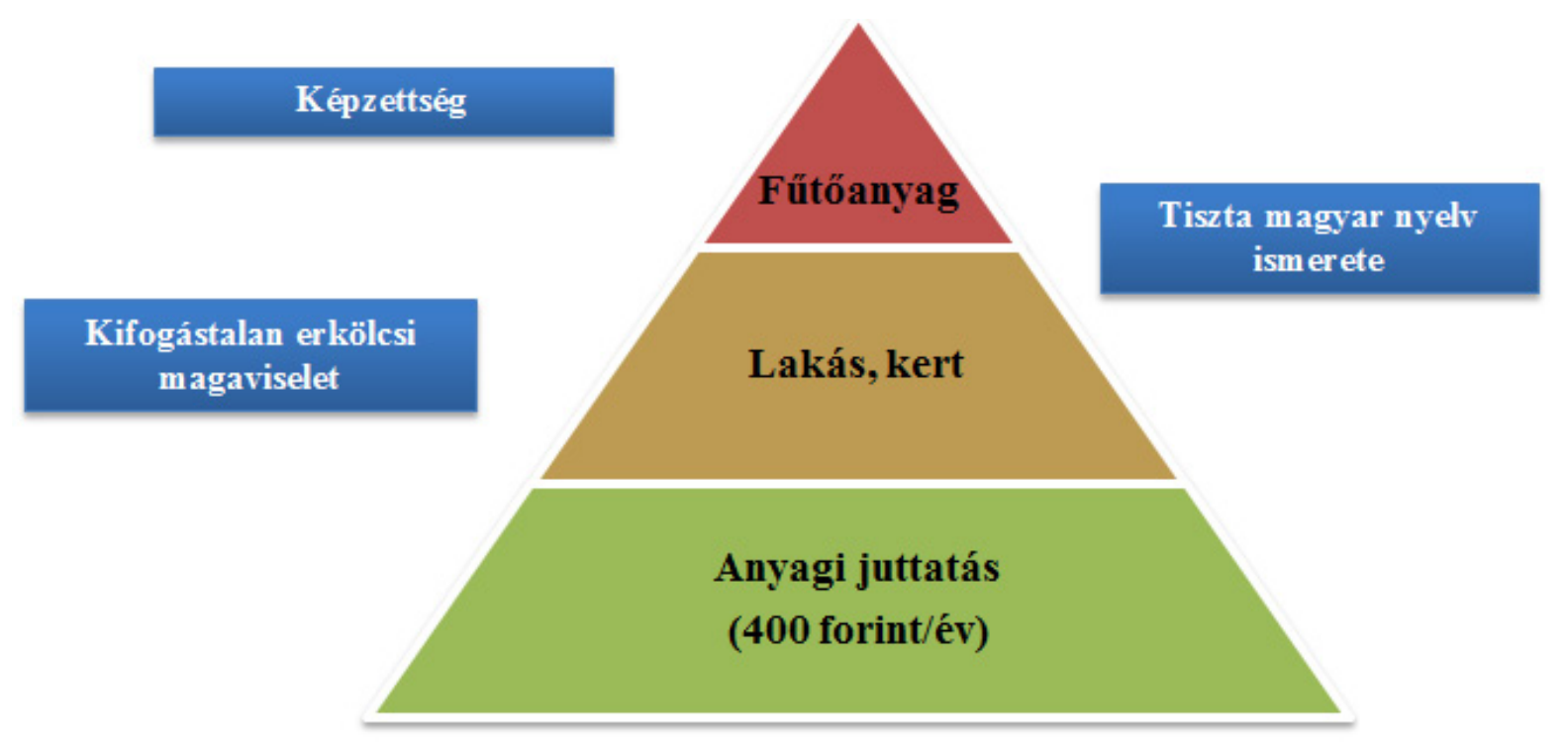

3. ábra: A javadalmazás és elvárás az 1880-as években

egyformán jogosultnak kell, hogy legyen. Egy, a gyermekkertésznő feladatait taglaló írásból kiemelendő annak módja, ahogyan a gyermek irányába fordulnia szükséges: „ellesni gondolataikat, érzelmeiket s az ő kedélyvilágukba magát beletalálnia; egyszóval legyen a gyermekek között gyermek" (Dömötör, 1880. 65. o.). Ebből teljességgel érződik, hogy a gyermeket a középpontba kell helyeznie és belőle kell kiindulnia, ha meg akarja ismerni, érteni, illetve nevelni és hatni szeretne rá. Valamint az is látható, hogy a nevelő „gyermeki” lényének meglétét fontos tulajdonságnak tartották.

Ez több másik cikkben is felmerülő gondolat, vagyis, hogy előbb a nevelőnek kell alkalmazkodnia a gyermekhez és miután megnyerte bizalmát, onnantól képes nevelőjévé válni és a tekintélyét megszerezni. A munkaköri tevékenységek között megjelent a napló vezetése, melyről ekképpen vélekedtek: a „gyermek lélek gyakorlati tanulmányozásának és a nevelés terén nagybecsü tapasztalatok gyüjtésének ez a legalkalmasabb módja" (Dömötör, 1880. 81. o.). Itt olyanok megfigyelések kerültek középpontba, mint a testi, lelki tehetségek, kedély, jellem alakulása, fegyelmi eljárások, büntetés-jutalmazás és ezek hatásai. Az akkoriban használatos napló talán még részletesebben foglalkozott az egyes gyerekekkel, mint a mai fejlődési naplók. Legfontosabb fegyelmezési eszköznek a nevelő helyes és jó példaadását tartották, valamint említés- re került a szeretet és azon alapuló nevelői tekintély a gyermekkel való együttérzés és gondolkodás eszméje. Itt is a nevelö felelösségét és szerepét említik, hiszen a gyermek az, aki fejlesztésre szorul, ő nem felelős a természetes hajlamai miatt, így „amilyen a nevelö, olyan a növendék" hangzik el (Székely, 1885, 204.o.). Azt is megemlíti a cikk szerzője, hogyha izgés-mozgás van társalgás vagy egyéb foglalkozás közepette, akkor nem a büntetés és a dorgálás a megfelelő fegyelmezési eszköz, hanem „én kutatom a szórakozottságot előidéző kútforrást és legtöbbször magamban keresve találom az okokat" (Székely, 1885, 229.o). Az saját munkáját átgondoltan tervező nevelő szerepe tűnik ki ebből, aki a saját módszereit vizsgálja felül, nem a gyereket tartja eredendően rossznak.

Ezekből láthatóvá válnak elvárások, melyeket a korszakban a kisdedóvókkal szemben támasztottak (4. ábra). Így a morális fedhetetlenség a bizalom, valamint a helyes, jó magatartás mellett, a gyermekek iránti őszinte szeretet, gyermekcentrikus gondolkodás, valamint a nevelő gyermeki lényének, belső fiatalságának megléte az ajánlott követelmény (4.ábra). A kisdedóvás törvényi szabályozásának előszobájaként is tekinthetünk mindezen elvárások megjelenésére, hiszen hosszas előkészültet követően 1891-ben lépett hatályba 




4. ábra: Elvárások a kisdedóvónővel/gyermekkertésznővel szemben (1880-as évek)

az a törvény ${ }^{1}$, mely elöször rendelkezett a kisdedóvásról (1891. évi XV. törvénycikk a kisdedóvásról). Meghatározásra kerültek a kisdedóvodák (vagy menedékhelyek) állításának feltételei, a nevelés célja és feladata, a felvehető gyermekek köre és maximális létszáma. Először szabályozták a képesítésre vonatkozó követelményeket, a kinevezés feltételeit és az óvók javadalmazását is megszabták.

\section{Összegzés}

Tanulmányomban a XIX. század végi szakfolyóiratokban fellelhető nőkről alkotott nézeteket vizsgáltam, kiemelt szereppel tekintve a nőnevelés kérdéseire és későbbi lehetséges hivatásukra, így a kisdedóvónőre. A választott évfolyamokból nagyjából hasonló vélekedéseket olvashatunk a nők szerepéről, amivel kapcsolatban legfőképpen a feleség és anya, valamint a nevelöi szerepkör tűnt ki.

Általánosan elmondható, hogy a nők korabeli fó tevékenysége az otthon melegének megteremtése, fenntartása volt, emellett pe-

\footnotetext{
1 A kisdedóvás törvényi rendezése már 1843-ban felvetődött, az 1848. évi egyetemes tanító-gyűlésen határozatban is kifejeződött. Az 1868-ban benyújtott népoktatási törvényjavaslatban benyújtásra is került, ám az ezt taglaló bizottság tagjai elvetették Báró Eötvös József elgondolásait. 1870-ben ismét benyújtotta a középtanodai és fötanodai törvényjavaslatokkal együtt, de ismét nem ért célt, majd 1871-ben elhalálozott. Törekvését P. Szathmáry Károly folytatta 1875-ben sikertelenül, majd az 1890. év hozta meg a változást Csáky Albin vallás- és közoktatásügyi miniszterelnöksége alatt. (Végh, 1937)
}

dig a férj szellemi társává és gyermeke művelt nevelőjévé is kellett válniuk. A lányok nevelése is leginkább ilyen téren valósult meg, vagyis ezen feladatok megfelelő ellátására törekedtek az ismeretek átadásakor. Kiemelten fontosnak vélték a konkrét ismereteken túl az erkölcsi tisztaságot, erényes viselkedést és ezekben példaadó szerepüket is többször kihangsúlyozták. Megjelenésükben a tisztaság és inkább az egyszerűségre való törekvés dominált, elitélően nyilatkoztak mindenfajta „cicomáról” és ferdeségek előidézőjeként is tekintettek ezekre.

A vizsgált időszakban kevesen gondolták úgy, hogy önálló karrier szükséges számukra, amely hivatásokat megfelelőnek tartottak azok is leginkább a gyerekek nevelésével kapcsolatosak - így például a tanítónői és óvónői pálya. Viszont elgondolkodtató az, hogy e karrierlehetőségek mennyiben járultak valóban hozzá ténylegesen ahhoz, hogy a nők önmagukat is képesek legyenek fenntartani abban a korban, de akár ma is felmerülhet ugyanezen hivatásokkal kapcsolatban ez a kérdés.

A cikkek női szerzőinek vélekedése alapján az is leszürhető, hogy maguk a nők sem voltak egyértelmű élharcosai ezen egyenjogúsági törekvéseknek, sőt némelyek komoly ellenvetésüknek is hangot adtak.

Összességében elmondható, hogy a nőkről, női szerepkörökről való gondolkodás ebben az időszakban is megosztotta a társadalmat, hiszen az egészen szélsőséges egyenjogúsítástól kezdve a teljes visszavonultságig nagyon sokféle nézet mentén alkottak véleményt a különböző szerzők. 
Nők a közgondolkodásban - a kisdedóvónő, mint lehetséges „karrierút”...

\section{Felhasznált irodalom}

1868. évi XXXVIII. törvénycikk a népiskolai közoktatás tárgyában

URL: https://1000ev.hu/index.php?a=3\& param $=5360$ (utolsó letöltés: 2017.03.29.)

1891. évi XV. Törvénycikk a kisdedóvásról URL: http://www.1000ev.hu/index.php?a=3\& param=6422 (utolsó letöltés: 2017.06.16.)

Aggné Pirka Veronika (2014): A magyar nőnevelés történetéhez - a XIX. századtól napjainkig. In: Aggné Pirka Veronika, Mikonya György, Mészárosné Darvay Sarolta, Szarka Emese: Kora gyermekkori nevelés és családtörténet. Budapest: ELTE Tanító- és Óvóképző Kar, 111-120.

Alexander Bernát (1880): Lélektani vádak a nők ellen. I. Nőismeret, női érdek. Nemzeti Nőnevelés, 1. kötet, 133-143.

Antal Gábor (1882): Pályázat kisdedóvói állomásra. Kisdednevelés, 11. 5. sz., 92.

Bánóczy József (1880): A nőkről. Nemzeti Nönevelés, 1. kötet, 77-78.

Bonyhai Benjámin (1885): Mezőberényi társulati kisdedóvóban. Kisdednevelés, 14. 9. sz., 214-215.

Budapest józsefvárosi kisdedóvó egylet (1880): Egyleti élet. Kisdednevelés, 9. 1. sz., 10-12.

Chabada József (1883): Pályázat. Kisdednevelés, 12. 8. sz., 136.

Csengery Antal (1880): A nőnevelésről. Nemzeti Nőnevelés, 1. kötet, 289-292.

Dömötör Géza (1880): Ébredjünk! Kisdednevelés, 9. 3. sz., 33-36.

Dömötör Géza (1880): A gyermekkertésznő feladata és kötelességei. Kisdednevelés, 9. 4. Sz. 49-51.

Dömötör Géza (1880): A gyermekkertésznő feladata és kötelességei. Kisdednevelés, 9. 5. sz., 65-67.

Dömötör Géza (1880): A gyermekkertésznő feladata és kötelességei. Kisdednevelés, 9. 6. sz., 81-85.

Dömötör Géza (1883): Reflexiók Eötvös K. Lajos úr fentebbi cikkére. Kisdednevelés, 14. sz. 3., 61-64

Dömötör Géza (1885): Báró Wesselényi Miklós a kisdedóvó-intézetekről. Kisdednevelés, 14. 11. sz., 249-251.

Danka István (1880): Egyletünk érdekében. Kisdednevelés, 9. 2. sz., 21-22.
Dixi (1880): Erkölcsi élet a kisdednevelés terén. Kisdednevelés, 9. 1. sz., 1-2.

György Aladár (1880): A nők a jótékonyság terén. Nemzeti Nőnevelés, 1. kötet, 28-30.

György Aladárné (1880): Néhány szó a nőiparkotatásról. Nemzeti Nőnevelés, 1. kötet, 79-81.

Ismeretlen szerző (1880): A kisdedóvó intézetek állapota 1879-ben. Kisdednevelés, 9. 3. sz., 43-46.

Ismeretlen szerző (1882): A kisdedóvó intézetek állapota 1880-ban. Kisdednevelés, 11. 2. sz., 27-30.

Ismeretlen szerző (1885): Ami legfontosabb. Kisdednevelés, 14. 1. sz., 3-5.

Eötvös K. Lajos (1885): Az óvóképezde kiegészítése. Kisdednevelés, 14. 3. sz., 49-50.

Kelemen Elemér (2000): Az óvoda a magyar társadalom történetében I. Óvodai Nevelés, 53. 4. sz., 138-141.

Kobány Mihály (1882): Falusi menhelyek állításánál mire kell első sorban kiváló tekintettel lenni? Kisdedóvók és gyermekkertésznök lapja, 1. 1. sz., 10.

Lederer Ábrahám (1880): Nőnevelés. Nemzeti Nönevelés, 1. kötet, 389-399.

Mikonya György (2014): Friedrich Fröbel és a kora gyermekkori nevelés. In: Aggné Pirka Veronika, Mikonya György, Mészárosné Darvay Sarolta, Szarka Emese: Kora gyermekkori nevelés és családtörténet. ELTE Tanító- és Óvóképző Kar, Budapest, 82-86.

Monori jótékony nőegyleti igazgatóság (1882): Pályázati hirdetés. Kisdednevelés, 11. 11. sz., 196.

P. Szabó E. (1882): Az én emlékeim. Kisdedóvók és gyermekkertésznók lapja, 1. 5. sz., 43-45.

P. Szathmáry Károly (1881): Kossuth Lajos a kisdedóvó intézetekről. Kisdednevelés, 10. 11. sz., 209-213.

P. Szathmáry Károly (1882): Az Országos Kisdedóvó Egyesület évi jelentése az 1881-ik évről. Kisdednevelés, 11. 7. sz., 124-128.

P. Szathmáry Károly (1883): Az Országos Kisdedóvó Egyesület évi jelentése az 1882-ik évről. Kisdednevelés, 12. 6. sz., 107-112.

P. Szathmáry Károly (1884): Az Országos Kisdedóvó Egyesület évi jelentése az 1883-ik évről. Kisdednevelés, 13. 7. sz., 125-129. 
P. Szathmáry Károly (1884): Felelet a kisdednevelés terén fölmerült aggodalmakra. 13. 8. sz., 141-143.

Péterfy Sándor (1880): Leányiskoláinknak a nemzeti művelődés nagyjelentőségű tényzőivé kell lenniök. Nemzeti Nönevelés, 1. kötet, $1-19$.

Péterfy Sándor (1882): Fröbel élete és működése. Nemzeti Nőnevelés, 3. 4. sz., 253-271.

Péterfy Sándor (1882): A magyarországi központi Fröbel-nőegylet működéséről. Nemzeti Nőnevelés, 3. 4. sz., 272-288.

Péterfy Sándor (1880): A nemzeti nőnevelésügy két nagy kérdéséről. Nemzeti Nőnevelés, 1. kötet, 241-250.

Pukánszky Béla (2006): Nőnevelés Magyarországon, a 19. században. In: A Nőnevelés évezredei. Gondolat Kiadó, Budapest.

Salamon Zsigmond (1882): Pályázati hirdetés. Kisdednevelés, 11. 11. sz., 196.

Somogyi Géza (1884): A nő munkaköre. Kisdednevelés, 13. 5. sz., 85-89.

Stetina Ilona (1880): Mire használhatja a nő ismereteit? Nemzeti Nönevelés, 1. kötet, 221-226.

Szász Károly (1882): A nő-képzésről. Nemzeti Nönevelés, 3. 1. sz., 1-16.
Székely Gábor (1884): A továbbképzés szüksége. Kisdednevelés, 13. 3. sz., 43-45.

Székely Gábor (1885): A rendelkezésünk alatt álló eszközök helyes fölhasználásával miként lehet a kisdednevelö-intézetek növendékei közt a megkívántató fegyelmet fentartani? Kisdednevelés, 14. 8., 203-206.

Székely Gábor (1885): A rendelkezésünk alatt álló eszközök helyes fölhasználásával miként lehet a kisdednevelö-intézetek növendékei közt a megkívántató fegyelmet fenntartani? (folytatás) Kisdednevelés, 14. 10. , 228-232.

Tisza Kálmánné (1880): Tisza Kálmánné és az országos kisdedóvó egyesủlet. Nemzeti Nönevelés. I. kötet, 214-220

Vadai Ferencz (1881): Pályázati hirdetés. Kisdednevelés, 10. 3. sz., 52.

Vegyesek rovat(1882): A Nyíregyház városi kisdedóvó intézet. Kisdedóvók és gyermekkertésznök lapja, 1. 1. sz., 11-12.

Végh József (1937): A budapesti magyar királyi állami óvónőképző-intézet százéves története (1837-1937). Pécs

Zichy Antal (1880): Széchenyi István gr. pedagógiai nézetei. Nemzeti Nőnevelés, I. kötet, 377-381. Women in public thinking - the appearance of preschool teaching as a possible female
'profession' in the nineteenth century's pedagogical journals

The author made a research on the appearance of thoughts about women in late nineteenth century's pedagogical journals, with special focus on preschool teaching as a possible female profession of the era. The paper starts with general thoughts about women's education which is followed by a deeper analysis of the journal's content. The appearance of women in public thinking is studied along three main topics: their roles in society at the time, the content and practical issues of girl's education, their possible profession and the thoughts about women's shortcomings in that period. The possible 'female career' of the era is presented in a separate chapter, including the entrance to preschool teaching, their training and requirements against them. The examination of the topic was based on the following journals: Nemzeti Nönevelés, Kisdednevelés and Kisdedóvók és gyermekkertésznők lapja, published between 1880-1885.

Keywords: women's history, history of girl's education, preschool teachers' training, pedagogical journal, content analysis

Janek Noémi (2017): Nők a közgondolkodásban - a kisdedóvónő, mint lehetséges „karrierút” a XIX. század végi pedagógiai szakfolyóiratok tükrében. Gyermeknevelés, 5. 2. sz., 76-88. 